\title{
Characterization of Fibers from Pineapple's Crown, Rice Husks and Cotton Textile Residues
}

\author{
Karen de Souza do Prado ${ }^{a}$, Márcia Aparecida da Silva Spinacé ${ }^{a *}$ \\ ${ }^{a}$ Centro de Ciências Naturais e Humanas - CCNH, Universidade Federal do ABC, \\ Av. dos Estados, 5001, Bangu, CEP 09210-580, Santo André, SP, Brazil
}

Received: July 23, 2014; Revised: May 17, 2015

\begin{abstract}
Fibers from pineapple's crown (PCF), rice husks (RH) and cotton textile residues (RTF) were characterized by SEM, X-ray diffraction, FTIR and thermogravimetric analysis. Moisture content, water absorption, density and the distribution of the diameter of the fibers were also evaluated. RTF showed cylindrical microstructure with smooth surface, PCF showed cellular structure and the microstructure of RH is globular, showing cell pattern of the outer surface epidermis which is well organized and has a corrugate structure. PCF and RH showed crystallographic planes of cellulose I and RTF showed a mixture of cellulose I and cellulose II. RTF showed the highest degree of crystallinity and the lower moisture content and water absorption. These results occur because the RTF has no hemicellulose, as verified by FTIR. Comparing the three fibers, the RTF presented the lowest density and diameter. Furthermore, the onset degradation temperature of RTF was $40{ }^{\circ} \mathrm{C}$ higher than the PCF and the RH.
\end{abstract}

Keywords: lignocellulosic fiber, cellulose, pineapple crown's fiber, cotton textile residues, rice husk

\section{Introduction}

Lignocellulosic material is one of the most promising natural, abundant and renewable feedstock for application in several areas such as bio-fuels, animal feeding, fine chemicals and composites ${ }^{1-3}$. Large amounts of lignocellulosic wastes are generated through agro-based processes such as biofuels and food productions are often disposed improperly in municipal landfills causing social, economic and technological harms. Thus, the use of lignocellulosic waste as reinforcement in polymer composites is an alternative to add value to the production process and to minimize these residues in the landfills. The agroindustrial residues were studied in this work in order to compare their properties as fibers and to verify if these fibers could be used as reinforcement in polymer composites. Three agrofibers wastes were studied: pineapple crown's fiber, rice husks and residual textile fibers. These wastes were chosen because i) Brazil is the third largest producer of pineapple (Ananas comosus) with around $7 \%$ of the world production what represents the world's fifth tropical fruit in harvested area. In the pineapple fruit, the crown corresponds to about $25 \mathrm{wt} \%$ and it is disposed as waste ${ }^{4-6}$; ii) rice is the third largest cereal crop of the world and the major staple diet which supplies $77.90 \mathrm{~kg} /$ capita / year of Asia population in $2007^{[7]}$. The rice husk is a by-product generated abundantly from rice milling industries and corresponds to about $20 \mathrm{wt} \%$ of the total rice production ${ }^{7,8}$. Most of these wastes of rice husk are disposed in a landfill and causes serious environmental pollution because of its difficult decomposition in the soil due to the high level of lignin and silica ${ }^{7,9}$; iii) Textile industry generates a great amount of cotton waste which is mainly composed of cellulose

*e-mail: marcia.spinace@ufabc.edu.br (about $90 \mathrm{wt} \%)^{10}$. In the cotton spinning process, wastes are generated by taking a large volume in landfills. In this work, fibers of pineapple crown's fiber (PCF), rice husks (RH) and cotton residue textile fibers (RTF) were characterized and evaluated for the use in polymeric composites.

\section{Experimental}

\subsection{Materials}

Textiles residues of cotton fibers were supplied by industries of Itupeva city, SP, Brazil. Perola cultivars (Ananas comosus) pineapples, were used to extract the pineapple crown and were obtained from popular markets of São Paulo-SP, Brazil. Rice husks were supplied by Industries in the South of Brazil.

\subsection{Preparation of fibers}

PCF were manually extracted and washed with distilled water at $80^{\circ} \mathrm{C}$ for $1 \mathrm{~h}$, and after they were dried in a conventional oven at $100^{\circ} \mathrm{C}$ for $3 \mathrm{~h}^{[11]}$. RH was ground in mills knives (Model SL-31, Solab) and sifted with a $7 \mathrm{~mm}$ sieve. RTF was used as received. Figure 1 shows picture of RTF, RH and PCF.

\subsection{Characterization}

The morphology of the fibers was analyzed by SEM (Jeol, Model JSM-6010 LA) with the samples coated with gold prior to the measurement (Bal-Tec, Multi Coating System MED020).

The diameter of about 100 fibers (for PCF and RTF) was determined using a micrometer calliper (Mitutoyo, $\pm 0.001 \mathrm{~mm}$ ). The diameter was measured at 3 points placed in three random locations along the length of fibers. 
The density of the fibers was determined in triplicate at $23{ }^{\circ} \mathrm{C}$ using a picnometer. The moisture content was evaluated in triplicate at room humidity of $55( \pm 7) \%$ and a temperature of $25( \pm 3){ }^{\circ} \mathrm{C}$. For this purpose, about $1 \mathrm{~g}$ of RH and RTF and about $0.2 \mathrm{~g}$ PCF were maintained in a conventional oven at $100( \pm 5){ }^{\circ} \mathrm{C}$ and the weight of the specimens were measured until constant weight.

The water absorption was determined in triplicate using about $1 \mathrm{~g}$ of RH and RTF and about $0.2 \mathrm{~g}$ PCF. The fibers were dried at $100( \pm 2)^{\circ} \mathrm{C}$ for $2 \mathrm{~h}$ and maintained at $24( \pm 6)$ ${ }^{\circ} \mathrm{C}$ in a desiccator containing a saturated solution of calcium chloride to maintain the relative humidity at $54( \pm 7) \%$. The weight of the samples was measured until constant weight, which occurred at about $600 \mathrm{~h}$. The percentage of moisture content and water absorption were calculated using Equation 1 where $W_{I}$ and $W_{F}$ are initial and final weight of specimens.

$W=\left(W_{I}-W_{F}\right) / W_{I}^{*} 100$

X-ray diffraction (XRD, Rigaku, model MiniflexII) patterns were measured with $\mathrm{CuK} \alpha$ radiation $(\lambda=1.541 \mathrm{~nm})$ at $30 \mathrm{kV}$ and $15 \mathrm{~mA}$. Scattered radiation was detected in the range of $(2 \theta)$ angle from 5 to $40^{\circ}$ at a speed of $2 \% \mathrm{~min}$. The resulting diffractograms were deconvoluted using Magic Plot Pro 1.5 software $\AA$ and the crystallinity index (CI) of the fibers was calculated by the Equation 2.

$\mathrm{CI}(\%)=\left(1-A_{\mathrm{a}} / A_{T}\right) * 100$

Where $A_{a}$ is the value of area under the curve related to the amorphous phase and $A_{t}$ is the total area of the diffractogram ${ }^{5,12}$.

FTIR (Perkin Elmer Frontier) measurements were made using $\mathrm{KBr}$ pellets in the range of $450-4000 \mathrm{~cm}^{-1}$, with $4 \mathrm{~cm}^{-1}$ resolution and 64 scans. The mixture of $\mathrm{KBr}$

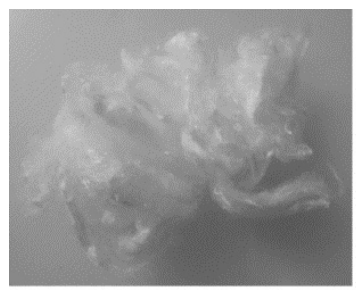

(a)

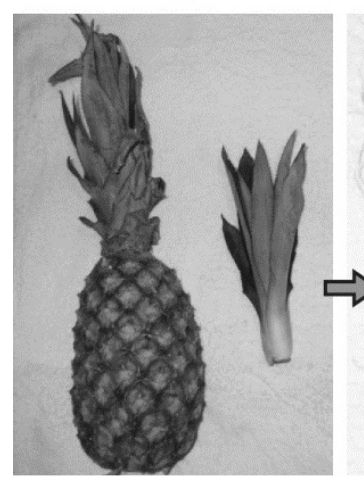

(c)

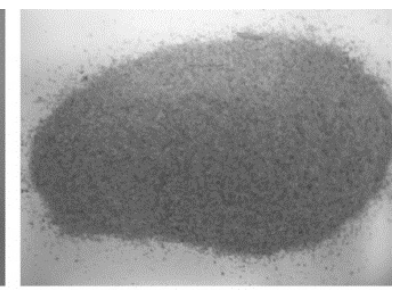

(b)

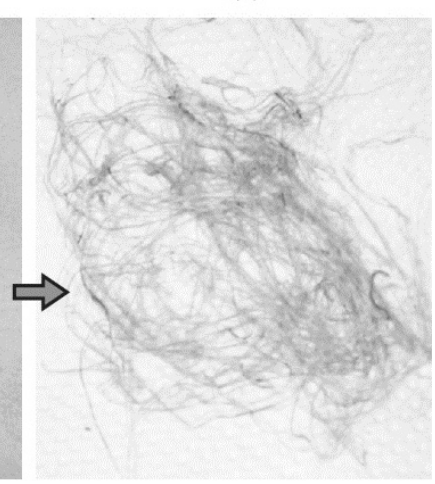

(d)
Figure 1. a) RTF, b) milled RH, c) pineapple crown's, d) PCF. and fibers was dried $\left(100{ }^{\circ} \mathrm{C}, 1 \mathrm{~h}\right)$ and the samples were prepared immediately before measurement.

Thermogravimetric analysis (TGA Q500 V20.8 TA Instruments) was made in the temperature range from $25^{\circ} \mathrm{C}$ to $800{ }^{\circ} \mathrm{C}$, at a heating rate of $10^{\circ} \mathrm{C} \cdot \mathrm{min}^{-1}$ in $\mathrm{N}_{2}$ atmosphere, with a flow rate of $50 \mathrm{~mL} \cdot \mathrm{min}^{-1}$ using about $10 \mathrm{mg}$ for each sample.

\section{Results and Discussion}

\subsection{SEM of the fibers}

RTF shows cylindrical microstructure with smooth surface and low diameter variation along the fiber (Figure 2a). This morphology is the result of pretreatment of the fiber during textile process. Nevertheless, the microstructure of PCF (Figure 2b) shows cellular structure and these cells together form fibrils with tissues connected with each other at several locations along the length to form fibers. Similar to most lignocelulosic fibers, PCF shows irregular cross section and diameter variations ${ }^{13}$. Furthermore, it can be seen traces of waxy materials and some damage in the fiber surface due to manual extraction process.

The microstructure of RH is globular showing cell pattern of the outer surface epidermis which is well organized and has a corrugate structure. The regular spherical platelets of almost equal sizes $(40-50 \mu \mathrm{m})$ appearing in parallel rows, (Figure 2c and d). Silica probable is present all over the fiber, but it is particularly abundant in the protuberances and fibers of the outer epidermis and somewhat less abundant in the inner epidermis adjacent to the rice kernel $^{13-15}$.

Mechanical interlocking due RH and PCF fibers surface roughness can promote adhesion interaction, mainly of the van der Waals type, between fiber and polymeric matrix ${ }^{16,17}$.

\section{2. $X$-ray diffraction (XRD)}

In the lignocellulosic fibers, cellulose is the main component and it has crystalline structure, while other components such as hemicellulose and lignin are amorphous ${ }^{18}$. Cellulose has a crystalline structure due to hydrogen bonding interaction and van der Waals forces between adjacent molecules ${ }^{19}$.

Native cellulose consists of two polymorphs, triclinic designated as $\mathrm{I}_{\alpha}$ and monoclinic polymorph designated as $\mathrm{I}_{\beta}$. According to the Sugiyana system ${ }^{20}$ the peaks at $2 \theta=14.7$, 16.1 and $22.5^{\circ}$ correspond to polymorph of cellulose I and can be designated as ( $1 \overline{1} 0),(110)$ and (200) crystallographic planes; while in the Meyer-Mark-Misch system the planes have indices (101), (101) and (002), respectively ${ }^{20}$.

Figure 3 shows RTF, PCF and RH diffractograms and the deconvolution was done in order to examine the intensities of the diffraction bands and to establish the crystalline and the amorphous areas more precisely.

The deconvolution of the X-ray diffraction profiles showed the presence of five peaks and an amorphous phase (Figure 3). For RH fibers, it was observed peaks at $2 \theta=15.3$, $16.4,20.1,22.3$ and $34.8^{\circ}$ and for PCF fibers were observed peaks at $2 \theta=15.1,16.2,20.6,22.7$ and $34.5^{\circ}$, which were assigned to the (101), (10 $\overline{1}),(012),(002)$ or (200) and (040) crystallographic planes of cellulose $\mathrm{I}^{21}$.

On the other hand, RTF is a mixture of cellulose I and II and showed peaks at $2 \theta=12.1,20$ and $21.9^{\circ}$ that were 
assigned to the $(1 \overline{1} 0),(101)$ and (200) crystallographic planes of cellulose $\mathrm{II}^{22,23}$, besides the peaks of cellulose I, (Figure 3 ). Cotton fiber was mercerized during the pre-treatment in the textile industry and this could change the crystalline structure of the cellulose contained in the resulting RTF fibers. On the other hand, PCF and RH were not pretreated and show polymorphic form, characteristic of native cellulose.

The crystallinity index (CI) calculated for PCF, RTF and $\mathrm{RH}$ fibers were $43.7,44.0$, and $25.9 \%$, respectively. Higher crystallinity could leads to higher tensile strength of the fibers ${ }^{24}$ and thereby improves the reinforcement of the polymeric composites.

\subsection{Fourier-Transform infrared spectroscopy (FTIR)}

FTIR spectra of the PCF, RTF and RH fibers (Figure 4) showed the typical bands of lignocellulosic fibers.

The strong bands at 3390,3440 and $3432 \mathrm{~cm}^{-1}$ of PCF, RTF and RH, respectively, are attributed to stretching of hydroxyl groups. For RTF these bands were broader than the ones observed for PCF and RH fibers. This could be explained since RTF fibers contain cellulose II and its structure is able to form more hydrogen bonds than cellulose I, resulting in a major broadening of these bands ${ }^{25}$.

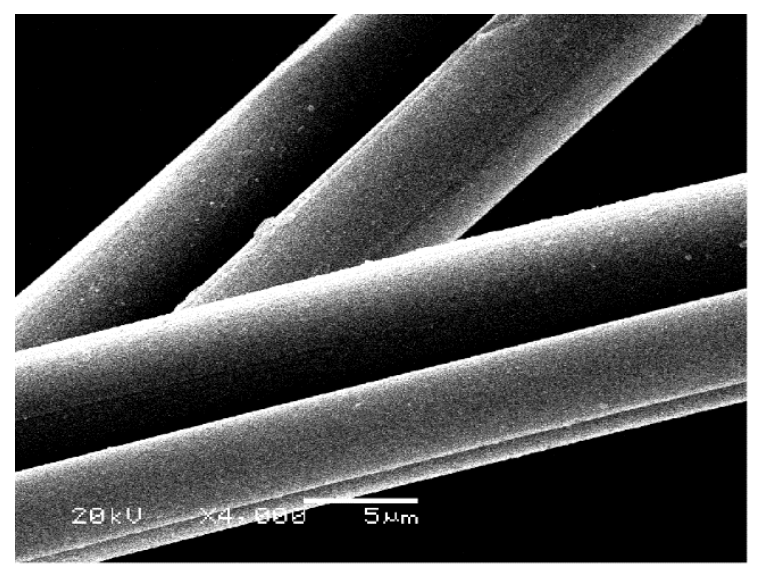

(a)

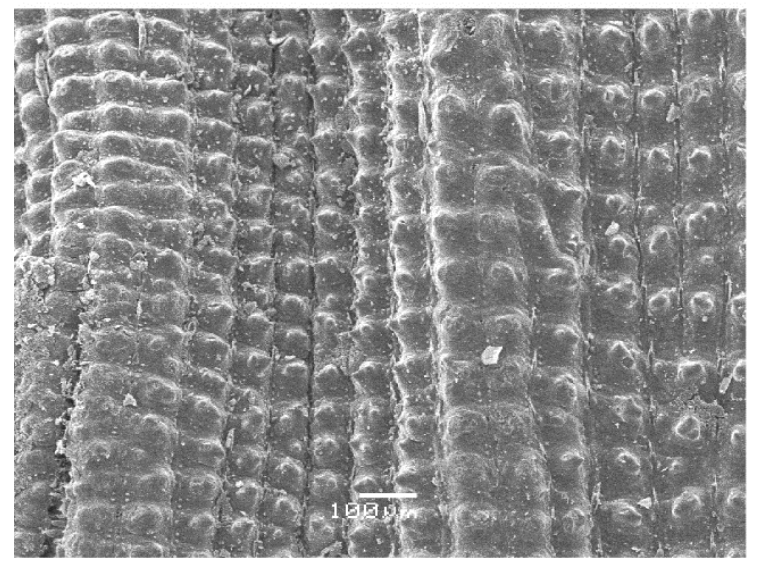

(c)
For all samples, the bands around 2910 to $2930 \mathrm{~cm}^{-1}$ are attributed to $\mathrm{C}-\mathrm{H}_{\mathrm{n}}$ asymmetric stretching present mainly in cellulose, which was the major component of the lignocellulosic fibers ${ }^{21,26}$.

The band near $1735 \mathrm{~cm}^{-1}$ assigned to unconjugated stretching vibrations of the $\mathrm{C}=\mathrm{O}$ of the carbonyl and acetyl groups in the xylan component of hemicellulose was clearly seen on PCF fibers and it was observed as a shoulder for RH fibers ${ }^{27-30}$. Absence of the peak at $1735 \mathrm{~cm}^{-1}$ leads to the hypothesis that RTF has undergone to alkaline scouring so most of the hemicelluloe were removed. The three fibers show a peak at about $1640 \mathrm{~cm}^{-1}$ related to absorbed water ${ }^{21,31-33}$

The bands at the region from 1000 to $1500 \mathrm{~cm}^{-1}$ are assigned to the aromatic region related to the lignin: the bands at 1460,1425 and $1220 \mathrm{~cm}^{-1}$ are characteristic of C-H and C-O deformation, bending or stretching vibrations of many groups in lignin and other carbohydrates ${ }^{28,29,34}$.

Cellulose show bands characteristics at 1055 and $1162 \mathrm{~cm}^{-1}$ attributed to C-OR stretching and antisymetric bridge C-OR-C stretching of cellulose, respectively ${ }^{28}$. The peak at $1320 \mathrm{~cm}^{-1}$ is attributed to the O-H of alcohol groups and the band at $1420-1430 \mathrm{~cm}^{-1}$ is assigned to aromatic skeletal vibrations associated to $\mathrm{C}-\mathrm{H}$ in plane deformation of cellulose. The band at $1375 \mathrm{~cm}^{-1}$ is related to $\mathrm{C}-\mathrm{H}$ bending in cellulose and hemicellulose ${ }^{29}$.

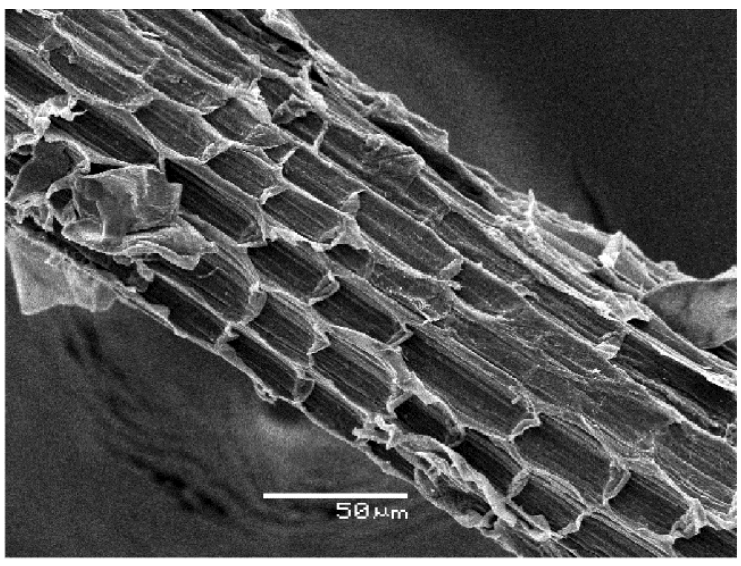

(b)

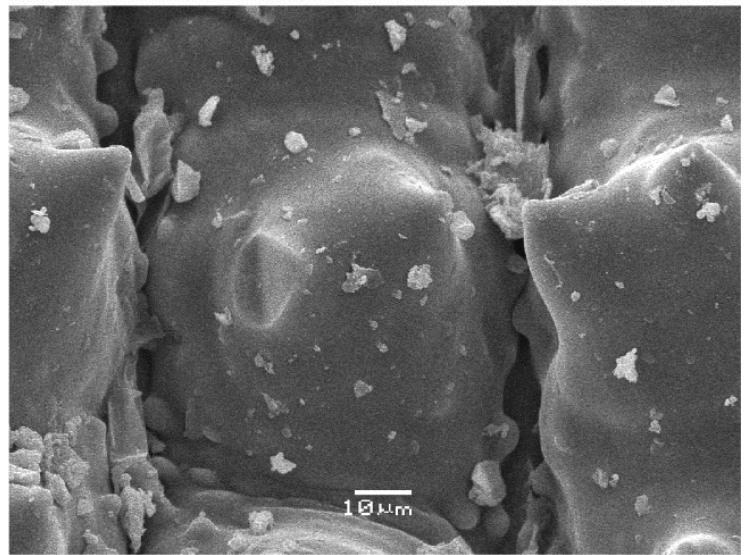

(d)

Figure 2. SEM micrographs of fibres surface: (a) RTF (bar: $5 \mu \mathrm{m}$ ), (b) PCF (bar: $50 \mu \mathrm{m}$ ), (c) RH (bar: $100 \mu \mathrm{m}$ ) and (d) RH (bar: $10 \mu \mathrm{m}$ ). 
The band at around $1420-1430 \mathrm{~cm}^{-1}$ is related to crystalline structure and the band at $898 \mathrm{~cm}^{-1}$ is attributed to $\mathrm{CH}$ deformation in the amorphous region of the cellulose $\mathrm{e}^{35}$.

For RH fibers, the intense band at $1047 \mathrm{~cm}^{-1}$ is related to the stretching vibrations of silicon-oxygen tetrahedrons and the relatively weak absorption band at $795 \mathrm{~cm}^{-1}$ is most

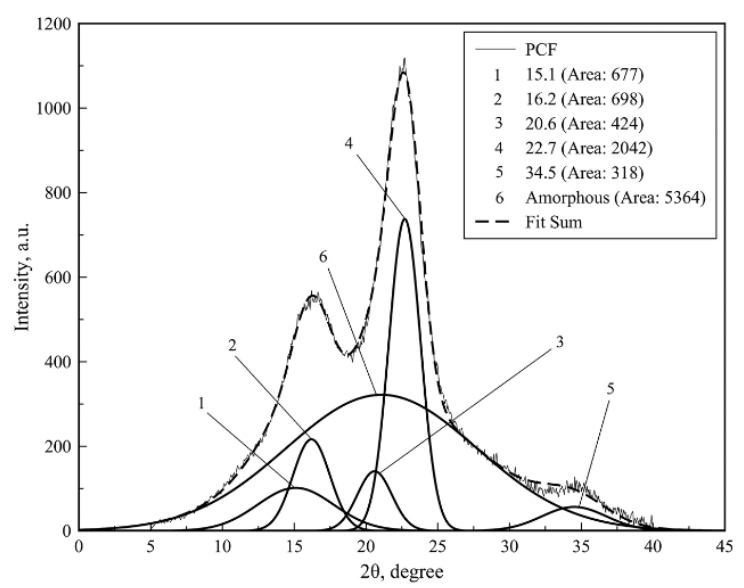

(a) likely linked to the symmetric and asymmetric vibrations of the $\mathrm{Si}-\mathrm{O}$ bonds in the silicon-oxygen network ${ }^{36}$.

FTIR of the lignocellulosic materials identifies the presence of components such as hemicellulose which giving them a hydrophilic character. This hydrophilic character could reduce the compatibility of the fibers with polymer matrices.

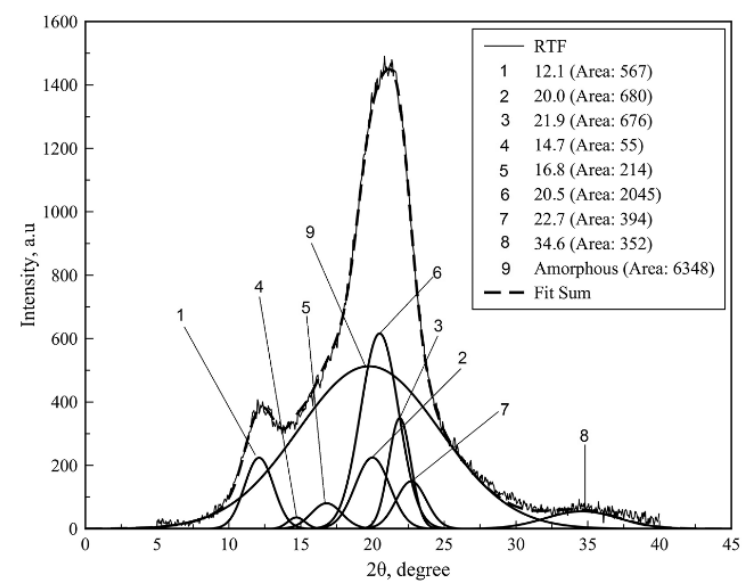

(b)

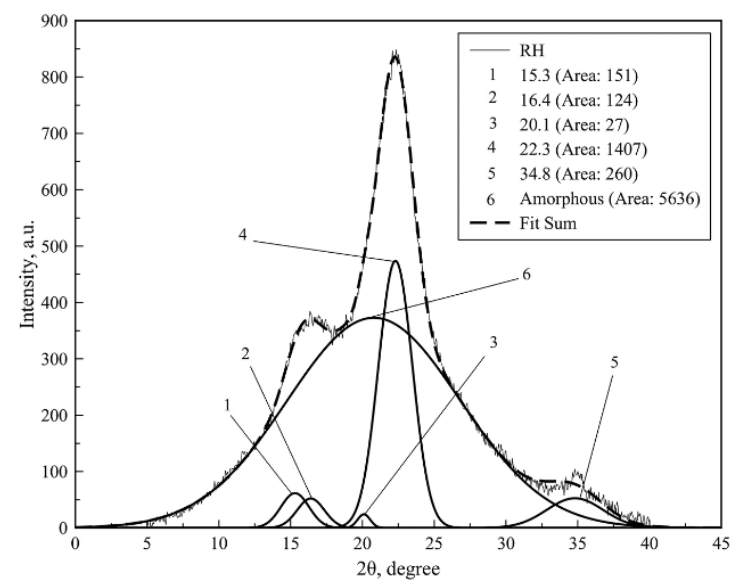

(c)

Figure 3. Deconvoluted X-ray diffractograms of PCF, RTF and RH fibers.

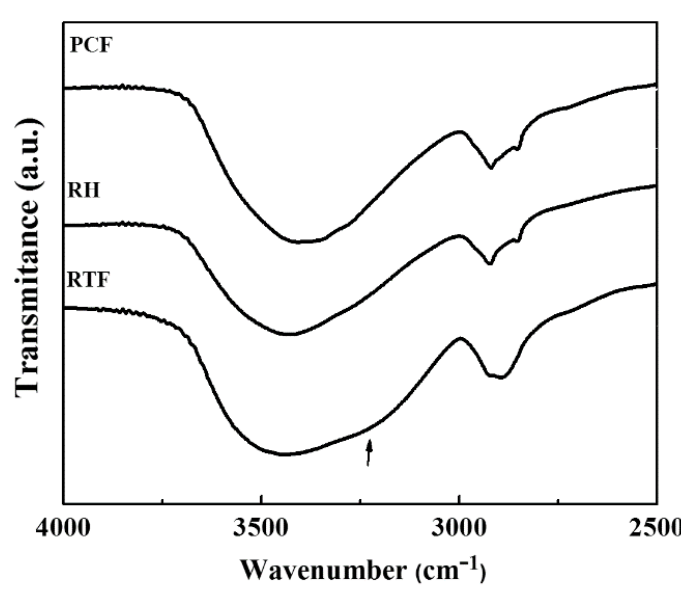

(a)

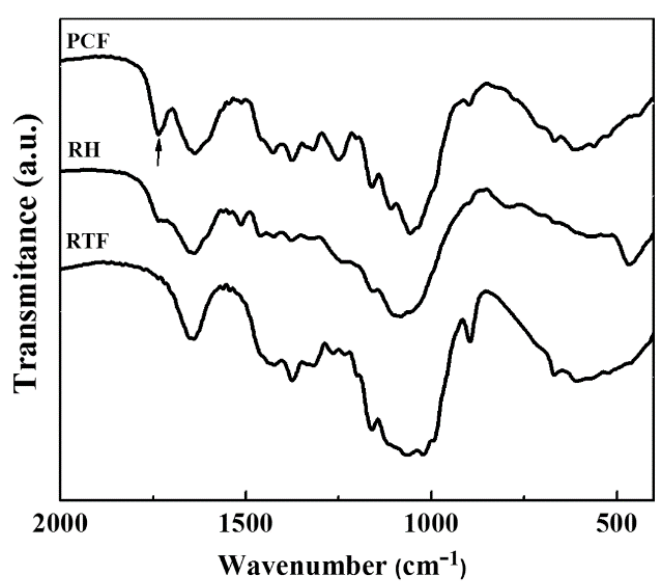

(b)

Figure 4. FTIR spectra of PCF, RH and RTF. 


\subsection{Density and diameter distribution of the fibers}

The values of density RTF, RH and PCF fibers (Table 1) are comparable with other fibers density, such as sisal $\left(1500 \mathrm{~kg} / \mathrm{m}^{3}\right)$, banana fiber $\left(1350 \mathrm{~kg} / \mathrm{m}^{3}\right)$ and the not-treated cotton, whose density varies between $1500-1600 \mathrm{~kg} / \mathrm{m}^{3}$, and all of them have densities smaller than the glass fiber $\left(2500 \mathrm{~kg} / \mathrm{m}^{3}\right)^{1,37}$. This result is interesting because the use of these fibers can reduce the weight of the polymeric composites.

The average diameter of RTF and PCF fibers are $14( \pm 5)$ and $18( \pm 12) \mu \mathrm{m}$, respectively; these values are lower than other fibers such as curaua and $\operatorname{sisal}^{38}$. The average diameter of $\mathrm{RH}$ was not determinate due this material was milled resulting in particle morphology whose dimensions depend on milling conditions.

The fibers diameter distributions were shown in Figure 5.

RTF fibers presented smaller diameter dispersion than PCF fibers. This result can be due to the extraction method of PCF fibers that causes fails in the fiber surface resulting in irregularity of the diameters. On the other hand, RTF fibers showed homogeneous diameter along the fiber due chemical treatment that extracted part of lignin, hemicellulose and particles on the fiber surface during textile process ${ }^{39}$.

Diameter distribution can be used to determine the aspect ratio (length/diameter) of the fiber. Aspect ratio (ratio between the length and the fiber diameter) is an important parameter to be taken into account in the improvement of fiber-matrix adhesion ${ }^{40}$.

\subsection{Moisture content and water absorption}

The lignocellulosic fibers moisture content depends on a lot of factors, such as composition, age and climatic conditions for development of the original plant ${ }^{37}$. Furthermore, it may

Table 1. Density, moisture content and fiber diameter of PCF, RH and RTF.

\begin{tabular}{cccc}
\hline Samples & $\begin{array}{c}\text { Density } \\
\left(\mathbf{k g} / \mathbf{m}^{3}\right)\end{array}$ & $\begin{array}{c}\text { Moisture }(\mathbf{w t} \\
\mathbf{\%})\end{array}$ & $\begin{array}{c}\text { Fiber diameter } \\
(\boldsymbol{\mu m})\end{array}$ \\
\hline PCF & 1273 & $18.0( \pm 0.6)$ & $18( \pm 12)$ \\
RH & 1405 & $10.7( \pm 0.5)$ & - \\
RTF & 1492 & $7.00( \pm 0.4)$ & $14( \pm 5)$ \\
\hline
\end{tabular}

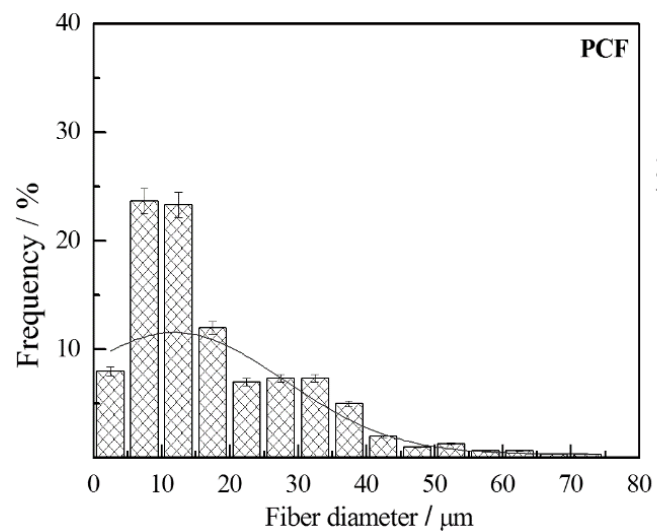

Figure 5. Fibers diameter distributions. also depend on the storage conditions and the time between the extraction and the use of the fiber residue. Moisture content in lignocellulosic affects physical and mechanical properties of the composite because cause a decrease in the fiber matrix-adhesion.

Table 1 show results of density, moisture content and fiber diameter of PCF, RH and RTF

The moisture content of the fibers, dependent on the content of non-crystalline parts and void content of the fiber, amounts up to $10 \mathrm{wt} \%$ under standard conditions and were normally described in the literature ${ }^{1}$.

Hemicellulose present in amorphous phase of the fibers have large amount of hydroxyl groups, which interact strongly with water by interactions of hydrogen. Thus, the higher hemicellulose content of the fiber increases the affinity with water. Therefore, the PCF fibers have the highest moisture content as can be verified by FTIR spectrum, which showed a peak at $1735 \mathrm{~cm}^{-1}$ corresponding to hemicellulose. RH fibers present a shoulder at $1735 \mathrm{~cm}^{-1}$ on FTIR spectrum indicating that the hemicellulose content was lower than PCF fibers. The low moisture content of the RTF fibers was related to the treatment of this fiber that was subjected to the spinning process, which removes the hemicellulose.

The time required for the fibers to reabsorb moisture is important to evaluate the mechanical properties of the composites during their useful life ${ }^{2}$. Figure 6 shows water absorption until $600 \mathrm{~h}$ of the PCF, RH and RTF.

For all fibers, the major part of water absorption occurred in the first $2 \mathrm{~h}$ and after $600 \mathrm{~h} \mathrm{PCF}$, RTF and RH fibers reabsorb $12.5,5.5$ and $8.2 \%$ of their total weight, respectively. However, all fibers absorbed less water than their original moisture content until $600 \mathrm{~h}$.

\subsection{Thermal properties}

TGA and DTG curves of PCF, RH and RTF fibers are shown in Figure 7.

The hemicelluloses degradation process of $\mathrm{RH}$ and $\mathrm{PCF}$ fibers started at 200 and $207^{\circ} \mathrm{C}$ and the temperatures of the maximum rate of degradation were observed at 290 and $291{ }^{\circ} \mathrm{C}$ with DTG of 0.35 and $0.25 \mathrm{wt} \% /{ }^{\circ} \mathrm{C}$, respectively; (Figure 7). For RTF fibers, the hemicelluloses degradation process was not observed. This result confirms the result

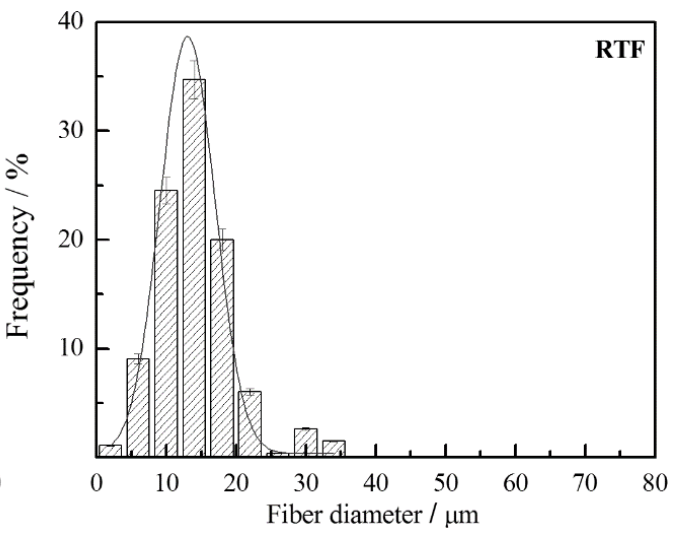



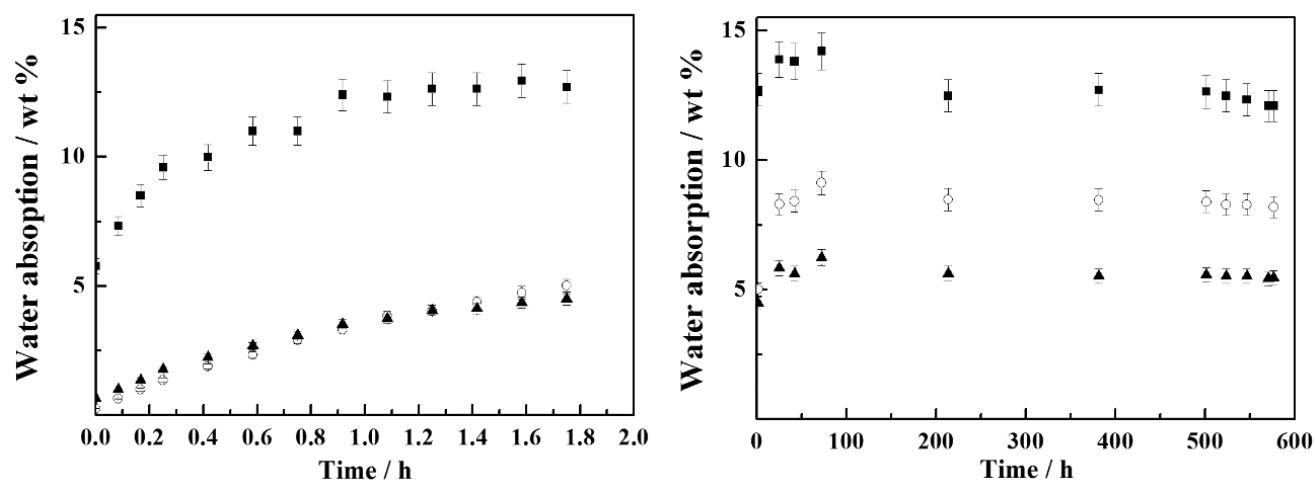

Figure 6. Water absorption: a) first $2 \mathrm{~h}$ and b) full time of the test for $\left({ }^{\bullet}\right) \mathrm{PCF} ;\left(^{\circ}\right) \mathrm{RH} ;\left(^{\boldsymbol{\Delta}}\right) \mathrm{RTF}$.

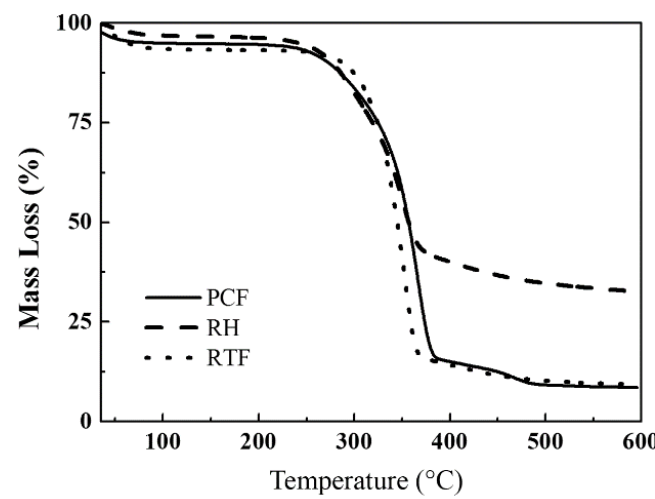

(a)

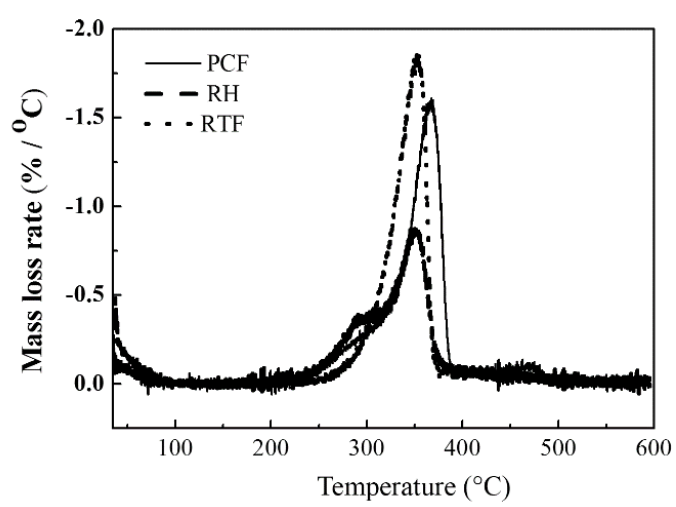

(b)

Figure 7. Thermal properties of RH, PCF and RTF: a) TGA and b) DTG curves.

of FTIR that showed the absence of the characteristic peak of hemicelluloses.

The cellulose degradation process for PCF, RH and RTF fibers occurred in the range from 257 to $390{ }^{\circ} \mathrm{C}$ and the temperatures of maximum rate of degradation were observed at 366,350 and $353{ }^{\circ} \mathrm{C}$ with DTG of 1.6, 0.8 and $1.8 \mathrm{wt} \% /{ }^{\circ} \mathrm{C}$, respectively. The end of thermal degradation of cellulose was observed above $390^{\circ} \mathrm{C}$ (Figure 7).

The solid residue was observed for PCF and RTF fibers above $500{ }^{\circ} \mathrm{C}$ and the value was approximately $8.8 \mathrm{wt} \%$, while for RH fibers the solid residue was already observed at a lower temperature $\left(370^{\circ} \mathrm{C}\right)$ and its value $(33 \%)$ was greater than the one observed for the other fibers. This residual mass may be associated with the presence of silicon ${ }^{15}$.

The amount of solid residue can also be related to the carbonization of lignin which is slow, and carbon could be the main product. Lignin is composed of three kinds of benzene-propane and is heavily cross-linked; this structure is different of cellulose and hemicellulose, which are composed of polysaccharides. Then, due to this structure the thermal stability of lignin is very high ${ }^{41}$.

RTF fibers do not contain hemicelluloses and its onset degradation temperature was about $40{ }^{\circ} \mathrm{C}$ higher than the PCF and RH fibers. This result is interesting because it allows the use of this fiber with polymer matrices having greater thermal stability.

\section{Conclusions}

The fibers studied showed differences in chemical and physical structures. RTF shows cylindrical microstructure with smooth surface, PCF shows cellular structure and the microstructure of RH is globular showing cell pattern of the outer surface epidermis which is well organized and has a corrugate structure. PCF and RH show crystallographic planes of cellulose I and RTF shows a mixture of cellulose I and cellulose II. RTF showed the major crystallinity degree because it does not have hemicellulose as it was seen by FTIR analysis. Besides, moisture content and water absorption are in accord to this result. Comparing the three fibers, the RTF presented the lowest density $\left(1273 \mathrm{~kg} / \mathrm{m}^{3}\right)$ and diameter $(14( \pm 5) \mu \mathrm{m})$. On the other hand, onset degradation temperature of RTF was about $40{ }^{\circ} \mathrm{C}$ higher than the PCF and RH fibers. Then, RTF showed the better properties for using in the polymeric composites. Concluding, these fibers of agroindustrial wastes showed properties comparable to commercial lignocelulosic fibers, so they are potentially able to act effectively as the dispersed phase in polymer composites, besides avoiding the deposition of this waste in landfills.

\section{Acknowledgements}

The authors are grateful for the financial support provided by the FAPESP (grant No. 2010/17804-7 and 2011/00156-5) and the CNPq (161853/2011-0, 310410/2010-0). 


\section{References}

1. Bledzki AK and Gassan J. Composites reinforced with cellulose based fibers. Progress in Polymer Science. 1999; 24(2):221274. http://dx.doi.org/10.1016/S0079-6700(98)00018-5.

2. Spinacé MAS, Lambert CS, Fermoselli KKG and De Paoli MA. Characterization of lignocellulosic curaua fibers. Carbohydrate Polymers. 2009; 77(1):47-53. http://dx.doi.org/10.1016/j. carbpol.2008.12.005.

3. Iqbal HMN, Kyazze G and Keshavarz T. Advances in the valorization of lignocellulosic materials by biotechnology: an over view. BioResources. 2013; 8(2):3157-3176. http://dx.doi. org/10.15376/biores.8.2.3157-3176.

4. Cordenunsi B, Saura-Calixto F, Diaz-Rubio ME, Zuleta A, Tiné MA, Buckeridge MS, et al. Carbohydrate composition of ripe pineapple (cv. perola)and the glycemic response in humans. Food Science and Technology (Campinas). 2010; 30(1):282288. http://dx.doi.org/10.1590/S0101-20612010000100041.

5. Sena AR No, Araujo MAM, Souza FVD, Mattoso LHC and Marconcini JM. Characterization and comparative evaluation of thermal, structural, chemical, mechanical and morphological properties of six pineapple leaf fiber varieties for use in composites. Industrial Crops and Products. 2013; 43:529-537. http://dx.doi.org/10.1016/j.indcrop.2012.08.001.

6. Granada GG, Zambiazi RC, Mendonça CRB. Abacaxi: produção, mercado e subprodutos. Boletim do Centro de Pesquisa de Processamento de Alimentos. 2004; 22(2):405-422.

7. Kuan CY, Yuen KH and Liong M-T. Physical, chemical and physicochemical characterization of rice husk. British Food Journal. 2012; 114(6):853-867. http://dx.doi. org/10.1108/00070701211234372.

8. Pauleski DT, Haselein CR, Santini JE and Rizzatti E. Características de compósitos laminados manufaturados com polietileno de alta densidade (PEAD) e diferentes proporções de casca de arroz e partículas de madeira. Ciência Florestal. 2007; 17(2):157-170.

9. Chandrasekhar S, Satyanarayana KG, Pramada PN, Raghavan $\mathrm{P}$ and Gupta TN. Processing, properties and applications of reactive silica from rice husk - an overview. Journal of Materials Science. 2003; 38(15):3159-3168. http://dx.doi. org/10.1023/A:1025157114800.

10. Satyanarayana KG, Guimarães JL and Wypych F. Studies on lignocellulosic fibers of Brazil. Part I: Source, production, morphology, properties and applications. Composites Part A: Applied Science and Manufacturing. 2007; 38(7):1694-1709. http://dx.doi.org/10.1016/j.compositesa.2007.02.006.

11. Martins MA. Fibra de sisal: mercerização, acetilação e aplicação em compósitos de borracha de pneu triturado [Thesis]. Campinas: Universidade Estadual de Campinas; 2001.

12. Teodoro KBR, Teixeira EM, Corrêa AC, Campos A, Marconcini JM and Mattoso LHC. Whiskers de fibra de sisal obtidos sob diferentes condições de hidrólise ácida: efeito do tempo e da temperatura de extração. Polímeros. 2011; 21(4):280-285. http://dx.doi.org/10.1590/S0104-14282011005000048.

13. Luo $S$ and Netravali AN. Interfacial and mechanical properties of environment-friendly "green" composites made from pineapple fibers and poly(hydroxybutyrate-co-valerate) resin. Journal of Materials Science. 1999; 34(15):3709-3719. http://dx.doi. org/10.1023/A:1004659507231.

14. de Lhoneux B, Gerlache L, Clemente A, Roda-Santos ML, Menaia JAG and Fernandes TH. Ultrastructural Characterization of Rice Husk Submitted to Different Pretreatments to Optimize its Fermentation. Biological Wastes. 1988; 23(3):163-180. http:// dx.doi.org/10.1016/0269-7483(88)90032-8.
15. Genieva SD, Turmanova SC, Dimitrova AS and Vlaev LT. Characterization of rice husks and the products of its thermal degradation in air or nitrogen atmosphere. Journal of Thermal Analysis and Calorimetry. 2008; 93(2):387-396. http://dx.doi. org/10.1007/s10973-007-8429-5.

16. Eichenlaub S, Gelb A and Beaudoin S. Roughness models for particle adhesion. Journal of Colloid and Interface Science. 2004; 280(2):289-298. http://dx.doi.org/10.1016/j.jcis.2004.08.017. PMid: 15533399.

17. Persson BNJ and Tosatti E. The effect of surface roughness on the adhesion of elastic solids. The Journal of Chemical Physics. 2001; 115(12):5597-5610. http://dx.doi.org/10.1063/1.1398300.

18. Johar N, Ahmad I and Dufresne A. Extraction, preparation and characterization of cellulose fibers and nanocrystals from rice husk. Industrial Crops and Products. 2012; 37(1):93-99. http://dx.doi.org/10.1016/j.indcrop.2011.12.016.

19. Zhang YH and Lynd LR. Toward an aggregated understanding of enzymatic hydrolysis of cellulose: noncomplexed cellulase systems. Biotechnology and Bioengineering. 2004; 88(7):797824. http://dx.doi.org/10.1002/bit.20282. PMid:15538721.

20. Mansikkamaki P, Lahtinen M and Rissanen K. The conversion from cellulose I to cellulose II in $\mathrm{NaOH}$ mercerization performed in alcohol-water systems: An X-ray powder diffraction study. Carbohydrate Polymers. 2007; 68(1):35-43. http://dx.doi. org/10.1016/j.carbpol.2006.07.010.

21. Popescu C-M, Singurel G, Popescu M-C, Vasile C, Argyropoulos DS and Willför S. Vibrational spectroscopy and X-ray diffraction methods to establish the differences between hardwood and softwood. Carbohydrate Polymers. 2009; 77(4):851-857. http:// dx.doi.org/10.1016/j.carbpol.2009.03.011.

22. Gonzales D, Lambert CS and Spinacé MAS. Nanocrystalline cellulose II extracted from cotton textile. In: Proceedings of the 7th International Symposium on Natural Polymers and Composites; 2010 September 7-10; Gramado, Brasil. Gramado: UFGRS; 2010. p. 1827-1830.

23. Cheng Q, Wang S and Han Q. Novel process for isolating fibrils from cellulose fibers by high-intensity ultrasonication. II. Fibril characterization. Journal of Applied Polymer Science. 2010; 115(5):2756-2762. http://dx.doi.org/10.1002/app.30160.

24. Joonobi M, Harun J, Shakeri A, Misra M and Oksman K. Chemical composition, crystallinity, and thermal degradation of bleached and unbleached kenaf bast (Hibiscus Cannabinus) pulp and nanofibers. BioResources. 2009; 4:626-639.

25. Bastidas J, Venditti R, Pawlak J, Gilbert R, Zauscher S and Kadla J. Chemical force microscopy of cellulosic fibers. Carbohydrate Polymers. 2005; 62(4):369-378. http://dx.doi. org/10.1016/j.carbpol.2005.08.058.

26. Adel AM, Abb El-Wahab ZH, Ibrahim AA and Al-Shemy MT. Characterization of microcrystalline cellulose prepared from lignocellulosic materials. Part II: physicochemical properties. Carbohydrate Polymers. 2011; 83(2):676-687. http://dx.doi. org/10.1016/j.carbpol.2010.08.039.

27. Popescu C-M, Popescu M-C and Vasile C. Structural changes in biodegradable lime wood. Carbohydrate Polymers. 2010; 79(2):362-372. http://dx.doi.org/10.1016/j.carbpol.2009.08.015.

28. Tanobe VOA, Sydenstricker THD, Munaro M and Amico SC. A comprehensive characterization of chemically treated Brazilian sponge- gourds (Luffa cylindrica). Polymer Testing. 2005; 24(4):474-482. http://dx.doi.org/10.1016/j. polymertesting.2004.12.004.

29. Poletto M, Zattera AJ and Santana RMC. Structural differences between wood species: evidence from chemical composition, FTIR spectroscopy and thermogravimetric analysis. Journal 
of Applied Polymer Science. 2012; 126(S1):E337-E344. http:// dx.doi.org/10.1002/app.36991.

30. Siqueira G, Bras J and Dufresne A. Luffa cylindrica as a lignocellulosic source of fiber, microfibrillated celulose, and cellulose nanocrystall. BioResources. 2010; 5(2):727-740.

31. Liang CY and Marchessault RH. Infrared spectra of crystalline polysaccharides I: Hydrogen bonds in native celulose. Journal of Polymer Science. 1959; 37(132):385-395.

32. Liang CY and Marchessault RH. Infrared spectra of crystalline polysaccharides II: Native celluloses in the region from 640 to 1700cm-1. Journal of Polymer Science. 1959; 39:269-278.

33. Schwanninger M, Rodrigues JC, Pereira $\mathrm{H}$ and Hinterstoisser B. Effects of short-time vibratory ball milling on the shape of FT-IR spectra of wood and cellulose. Vibrational Spectroscopy. 2004; 36(1):23-40. http://dx.doi.org/10.1016/j.vibspec.2004.02.003.

34. Silva MC, Lopes OR, Colodette JL, Porto AO, Rieumont J, Chaussy D, et al. Characterization of three non-product materials from a bleached eucalyptus kraft pulp mill, in view of valorizing them as a source of cellulose fibers. Industrial Crops and Products. 2008; 27(3):288-295. http://dx.doi.org/10.1016/j. indcrop.2007.11.005.

35. Åkerholm M, Hinterstoisser B and Salmén L. Characterization of the crystalline structure of cellulose using static and dynamic FT-IR spectroscopy. Carbohydrate Research. 2004; 339(3):569-578. http://dx.doi.org/10.1016/j.carres.2003.11.012. PMid:15013393.
36. He D, Ikeda-Ohno A, Boland DD and Waite TD. Synthesis and characterization of antibacterial silver nanoparticle-impregnated rice husks and rice husk ash. Environmental Science \& Technology. 2013; 47(10):5276-5284. http://dx.doi.org/10.1021/es303890y. PMid:23614704.

37. Aquino EMF, Sarmento LPS, Oliveira W and Silva RV. Moisture effect on degradation of jute/glass hybrid composites. Journal of Reinforced Plastics and Composites. 2007; 26(2):219-233. http://dx.doi.org/10.1177/0731684407070030.

38. Spinacé MAS, Janeiro LG, Bernardino FC, Grossi TA and De Paoli M-AD. Poliolefinas Reforçadas com Fibras Vegetais Curtas: Sisal vs. Curauá. Polímeros. 2011; 21(3):168-174. http://dx.doi.org/10.1590/S0104-14282011005000036.

39. Klemm D, Heublein B, Fink HP and Bohn A. Cellulose: fascinating biopolymer and sustainable raw material. Angewandte Chemie International Edition. 2005; 44(22):3358-3393. http://dx.doi. org/10.1002/anie.200460587. PMid:15861454.

40. Puglia D, Terenzi A, Barbosa SE and Kenny JM. Polypropylenenatural fibre composites. Analysis of fibre structure modification during compounding and its influence on the final properties. Composite Interfaces. 2008; 15(2-3):111-129. http://dx.doi. org/10.1163/156855408783810849.

41. Yang H, Yan H, Chen H, Zheng C, Lee DH and Liang DT. Indepth investigation of biomass pyrolysis based on three major components: hemicellulose, cellulose and lignin. Energy \& Fuels. 2006; 20(1):388-393. http://dx.doi.org/10.1021/ef0580117. 